\title{
IMPROVING STUDENTS' SPEAKING ABILITY BY USING EXAMPLE Non-EXAMPle Technique at SECOND Grade OF State Junior SCHOOL 1 LARANGan PAMEKASAN
}

\author{
Arisandi Setiyawan, Ina Daril Hanna \\ University of Islam Madura \\ ase.sun86@gmail.com, Ina.daryl@yahoo.com
}

\begin{abstract}
This study is a classroom action research (CAR). This study proposed example non example technique to teach English for second grade students at state junior high school 1 Larangan Pamekasan to solve the students' problems on speaking skill. The result of the preliminary study indicated that the problem of the students toward their speaking skill is the average speaking score is lower than the minimum standard of learning (KKM). Based on the pre-test, the students who got score more or equals to 75 are 7 students and 33 students got less 75 . Then the researchers collaborated with the teachers try to solve the problem using example non-example technique using classroom action approach. The results showed that the instruction through example non-example technique in the Cycle I and Cycle II, there was improvement of students' speaking ability at second grade of state junior high school 1 Larangan Pamekasan. The students were more imaginative and feel free to show their understanding about the pictures. It made them motivate to learn and they could improve their speaking ability.
\end{abstract}

Keywords: speaking ability, example non-example technique, classroom action research

\section{INTRODUCTION}

Learning English is very important for people. In this case, learning means that formal study of language rules and its conscious process. Jack C. Richard, Theodore S. Rodger (2008:22). As one of international language, English is also considered as important language to be taught. Moreover, In Indonesia, the students learn English as a compulsory subject especially for students at junior high school, and its implementation is applied based on the Content Standard. Meanwhile the objective is that the students can reach an informational level of literacy. On the other hand, the students are expected to be able to get knowledge by using English (Depdiknas, 2007). According to Brown (2007:284) the English skills consist of four, those are speaking, listening, reading and writing. Furthermore, Speaking is considered as an important skill because there is a connection between speaking and human being and it cannot be separated to each other. Speaking is used to express ideas and to communicate to people in every single day.

Meanwhile, Richards and Renandy (2008:201) states that the capability to speak a foreign language fluently is a very complex task if we try to understand the nature of what appears to be involved. To begin with, the purposes of speaking vary and every purpose needs different skill. In casual conversation, for example, the purpose can be to make social contact which occupies much of time people spend with friends. Meanwhile when people having discussion, the purpose may be to find or express opinions, to persuade someone about something, to clarify information, to give instructions or get things done, to describe things, to complain people's behavior, and to make polite request.

Dealing with speaking skill, students have to know the elements of speaking, such as vocabularies, pronunciation, grammar, and also fluency. The students in Indonesia are classified as a foreign learner of English, therefore even though students in have amount of vocabularies and master the grammatical structure, but the students still find it difficult to speak. This condition also appears to the students at second grade of state junior school 1 Larangan Pamekasan.

Based on the observation, the students' difficulties occur when the teacher asked the students to express their idea using English. The students' limitation in mastering the component of speaking is considered as the reason for that condition. Besides, the students rarely speak English in their daily life. English is not their environment and they have a little chance to practice speaking English out of class because they of course tend to speak Madurese as their mother tongue. In other word, the environment is not the English environment.

On the other hand, English teacher plays an important role in education, especially in teaching and learning process, in this case, English teacher have to apply the appropriate technique in teaching 
speaking. One of the techniques that can be used to teach speaking is examples Non-examples technique.

Furthermore, Slavin (1991:36) defines that Example Non-Example Technique is a technique that encourages students to analyze the example through pictures given by the teacher. Here, the students ask, give and share their ideas to complete a specific task in group. The students have to master the topics they are discussing deeply since they are having a short presentation about the pictures and prepare the answer toward teacher's questions orally. It is a strongly challenged technique that makes students plan themselves to deliver their ideas before they perform it in front of the class. Furthermore, Kagan (1992:32) Convinces that in applying Example Non - Example Technique, the teachers should consider two principles; (1) Examples refer to the real samples given by the teacher through pictures related to the topics discussed that should be understood by students. (2) Non- Example are the samples that do not match with the topic discussed. As we know that picture is a very attractive media in teaching process so that students are interested in learning English. It is in line with Carol (2001:51) mentions that picture is a popular media to elicit oral language performance of both intensive and extensive levels moreover, Harmer (2007:92) states that pictures is an interesting media due to its simplicity and attractiveness.

Based on the background above, the writers believe that Examples non-Example as one technique of cooperative learning becomes the alternative earning becomes the alternative solution to enhance students' speaking performance.

\section{MATERIALS AND METHODS}

The research intends to improve the students' speaking skill by using the example non-example technique. Therefore, the research design which is applied is Classroom Action research (CAR). Kemmis and Mc Taggart (1998:15) state that "action research is an action which is conducted to inquire self-reflective and improve his or her instruction by evaluating his or her own practice". It covers the research design or planning, implementation, observation, reflection and data analysis.

Since the study is Classroom Action Research, so the study is conducted in a cycle process and the steps in every cycle consists of planning, implementing, observing the process, reflecting, as proposed by Kemmis and MC Taggart (1988). The process was stopped when the researcher found that students have reached the criteria of success and the problem was considered to be solved.

Planning is the step that should be taken on the classroom action research. It can be used as a guideline for the teacher in applying the teaching and learning process. The researcher arranges preparing everything needed for applying the action such as preparing teaching procedure and designing lesson plan. Before teaching through example non example technique, the researcher disigned a lesson plan. It includes (1) Instructional objectives, (2) Instructional media, (3) Teaching and learning activity.

Field note is used to collect data related to situation of class (subject) gain in teaching learning process from cycle I and cycle II go on. This data is used for the improvement of learning the next cycle.

Observation was used by the researcher to get data directly concerning the effectiveness of using Example Non-Example technique to improve the speaking skill of the students and also to get the problem faced by the students in teaching and learning process.

In addition, the best way to know the students' improvement in undergoing the material is a test. The test was categorized as oral test of speaking performance. It is used to gain the score of students' achievements concerning their speaking performance. This oral test was as an instrument to collect the data or information and as a guide of the researcher in conducting assessment to word speaking skill. It was conducted at the end of teaching and learning process.

There are two kinds of test: the first is pretest, it was conducted to get data from students' achievement in speaking ability before implementing the Example Non-Example technique. The second was post-test, it was used to get the data of students' speaking skill after the implementation of Example Non-Example technique.

The quantitative data were obtained from the students' speaking performance grades in the criteria of vocabulary performance, grammatical accuracy, pronunciation, and fluency in the analytic scoring rubrics. The students were considered to be successful if more than $50 \%$ of the students can get more or equal to 75 as the criteria of success. 


\section{RESULTS AND DISCUSSION}

\subsection{Finding of Preliminary Study}

In this phase, the researchers conducted preliminary study through interview and pre-test. This phase was conducted in order to know the students' speaking ability of the second grade of state junior school 1 Larangan Pamekasan.

Based on the interview conducted to the teacher, the researchers found some difficulties faced by the students at second grade of state junior school 1 Larangan Pamekasan in speaking English. Finally, the researcher tried to solve the students' problem by collaborating with the teacher.

By giving test, the researchers found that the speaking ability of the students was quite low. Based on the score of pre-tests, the students who got score more or equals to 75 are 7 students and 33 students got less than 75 .

It can be said that the students who passed pre-test of speaking succesfully were $17,5 \%$ and 82,5 $\%$ of the students failed. it means the score of students' speaking ability was still under the criteria of success.

\subsection{Finding OF CYCLE 1}

\subsubsection{PLANNING}

In this phase, the researcher prepared lesson plan, materials, teaching media, and research instrument. The preparation of those conducted several days before the researcher conducted the action of the Example Non-Example technique. In this phase, the researcher decided the material and some exercises by using Example Non-Example technique. The researchers also prepared checklist to make an observation about students' activities in teaching learning process whether it is in accordance with the lesson plan had been designed before or not. Then the researchers designed post-test 1 to know whether there were some improvements for the students' score between pre-test and post-test.

\subsubsection{ACTING}

The action on the first cycle started at 08.20 WIB finished at 9.40. The researcher introduced himself to students. And then the researcher explained Example non example technique that would be used in their speaking class.

The researcher made all of students sit in circle and explained what actually Example non example is, benefit of Example non example, and a good way of completing the Example non example. The researcher gave a text of meeting "my idol". The researcher gave example to be a good completer and then asked the students about the difficult words. Last, researcher pointed one of the students to stand up and asked student to explain the pictures which they read in front of the class.

\subsubsection{OBSERVING}

This observing phase was actually done at the same time as acting. So the researcher did observing just one meeting of the action of example non example technique.

Based on of the pre-test, the researcher found that most of the students still found it difficult in understanding the pictures. They were afraid and shy of making mistakes in speaking. So the students could not explain the pictures well. In conclusion, students' speaking score were still under the criteria of success. In this test, 12 students could get score more or equals to 75 and 28 students couldn't get it yet.

\subsubsection{REFLECTING}

The researcher conducted reflecting in the last meeting of every cycle. So, there were two reflection in this classroom action research. According to the observation sheet in analyzing the teaching and learning process for speaking by using example non example technique in cycle 1 , it was found that most of the students' speaking ability was still low. The precentage of success was $30 \%$. It means that there were 11 students could get score more or equals to 75 and 29 students could not get it yet. Although there was some improvement in their score, but the criteria of success have not been achieved yet. In conclusion, the action of the strategy in cycle 1 is still needed to be revised. 


\subsection{FINDING OF CYCLE 2}

\subsubsection{REVISED PLANNING}

The action in cycle 1 had not given a significant change to the speaking skill of the students at second grade of state junior school 1 Larangan Pamekasan. The result of test in cycle 1 was not satisfying yet. So, some revisions on the planning were made. The planning of the acting in cycle 2 was similar with cycle 1 . But the diferences were the reseacher made a group and the researcher used media to deliver the materials. The media was put on the blackboard and ask the students to choose and explain the pictures.

\subsubsection{ACTING}

In this phase, the researchers gave the pictures to students. The researchers made group consisting of 5 students. The researcher asked the students to discuss together and then asked about the difficult words. Later, the researcher asked the students to discuss and understand and remember about the pictures. Last, in this meeting, the researcher asked students to explain the pictures which they discuss and understand in their group one by one in front of the class by using their own language. In this posttest, 23 students could get score more or equals to 75 and 17 students still couldn't get it.

\subsubsection{OBSERVING}

The observation was focused on the activities done by the students during teaching and learning process. In this phase, most of the students were not afraid of making mistakes in speaking. They were more active and enthusiastic because they were on group and they could think some pictures on the blackboard. In effect, the students could speak well.

\subsubsection{REFLECTING}

Based on the observation from the analysis of the teaching and learning process in speaking by using example non example technique in cycle 2, it was found that most of the students got improvement in speaking. The students were more active and enthusiastic during teaching and learning process. There were 17 students or $45 \%$ who could not achieve the criteria of success. It means, 23 students could achieve KKM (standard of minimum score) so 57,5\% of the students were successful and the criteria of success could be achieved.

\subsection{DisCUSSION}

From the result of the action of example non example technique, there was the improvement of speaking ability at the second grade of state junior school 1 Larangan Pamekasan. The students were more imaginative and feel free to show their understanding about the pictures. It made them motivate to learn and they could improve their speaking ability. The score of mean of the students before acting of example non example was 59. And the score of mean of the students after acting example non example was 68.

It can be concluded that there was an improvement in speaking skills of the students at second grade of state junior school 1 Larangan Pamekasan. From pre-test there were 7 students $(17,5 \%)$ who could achieve minimum standard (KKM). So, there were 33 or $82,5 \%$ students could not achieve minimum standard.

From the second test on the first cycle, there was improvement of speaking skills of the students but the criteria of success coud not be achieved yet. There were 12 students (30\%) who could achieve minimum standard (KKM). So, there were $28(70 \%)$ students could not achieve minimum standard. In conclusion, the action of example non example technique is needed to be revised.

The target of success is $50 \%$ of the students can get speaking score more than or equals to 75 as the minimum standard or KKM (Standar Ketuntasan Minimum). Finally, from the result of post-test from the second cycle showed that the criteria of success could be achieved. There were $23(57,5 \%)$ students who could acieve minimum standard (standar ketuntasan minimum) and 17 (42,5\%) students were still could not achieve yet

From the result in pre-test, test in cycle 1 and test in cycle II was getting improvement, in pre-test mean score was 59, after that researcher used a example non example technique in teaching speaking, in the cycle I the students score of test doesn't improve 30\%.So that the researchers continued to the next cycle (cycle II), and the result of cycle II was successful, the students' score in test was improve 
$57,5 \%$.So that, the use of example non example brought a positive impact to the students' speaking skill.

\section{CONCLUSION}

According to the result of data analysis, the researcher concluded that teaching English using Example Non-Example Technique (ENET) is effective and it can improve students' speaking ability. It is supported by several data such as: observation result which shows that students enthusiastic in participating the teaching and learning process. They also motivated the students in learning speaking and reduced the hesitation in practicing their speaking.

In preliminary study the students' average score was 59.125, then the researcher concluded that there were only $17.5 \%$ of students pass the KKM, in the cycle I, the students average score was 62.625 , and there were $30 \%$ could pass the KKM. In the cycle II the students got average score 68.125 , and the students passed KM were 23 students, it means that $57.5 \%$ of the students passed the KKM. From the result above it could be concluded that the use of Example Non-Example Technique (ENET) could improve students' speaking ability.

The researcher suggests that the teacher should use various methods in the classroom because the teacher has to pay attention and be selective in choosing a teaching method in improving students' speaking ability.

For the next researcher the instruction of each part must be very clear, easy to understand and it is provided with examples.

\section{REFERENCES}

Brown, H. Douglas. (2007). Teaching by Principle an Interactive Approach Language Pedagogy. San fransisco: Addison Wesley Longman.

Carol, B. (2001). Gifted kid, Cooperative and Collaborative Learning Strategy. Retrived (Online), http://giftedkids.about.com (accessed on 16th of Desember 2017).

Depdiknas. 2007. Kurikulum KTSP Mata Pelajaran Bahasa Inggris SMA dan MA. Jakarta: Badan Standar Nasional Pendidikan

Kagan, S. (1992). The Structural Approach to Cooperative Learning in Cooperative Learning: A response to Linguistics and Cultural Diversity. Edited by Daniel. London: Longman Inc.

Richards, Jack. C. and Willy A. Renandy. (2008). Methodology and Language Teaching. New York: Cambridge University Press.

Slavin, R. E. (1991). Speaking Perspectives in the Classroom: cooperative learning Method 
